ANNA SUCHAŃSKA (iD orcid.org/0000-0003-4462-7588

Wyższa Szkoła Bankowa, Poznań

WSB University, Poznań e-mail: anisu@amu@edu.pl

\begin{abstract}
ALEKSANDRA PILARSKA (D) orcid.org/0000-0002-9507-8710
Instytut Psychologii, Uniwersytet im. Adama Mickiewicza, Poznań Institute of Psychology, Adam Mickiewicz University, Poznań, Poland e-mail: alpila@amu.edu.pl
\end{abstract}

JAGODA BRZEG

Poznań

\title{
Przywiązanie i kompetencje samoopiekuńcze w wyjaśnianiu pośredniej autodestrukcyjności
}

\author{
Attachment and Capacity for Self-care \\ in Explaining Chronic Self-Destructiveness
}

\begin{abstract}
The study aimed to analyze the role of attachment in the formation of chronic selfdestructive tendency. It was hypothesized that high levels of attachment anxiety and avoidance impair self-care functions and limit capacities for self-control, which may then lead to the development of an indirect self-destructive personality pattern. The study was conducted among 137 young adults, using the Chronic Self-Destructiveness Scale, Experiences in Close Relationships Scale, Self-Control Scale and Self-Care Competence Questionnaire. The obtained results showed that the relationship between anxiety about rejection and chronic self-destructiveness was only indirect - its influence was primarily through self-control and partly also through self-care functions. With regard to avoidance of intimacy, the analysis revealed it had both direct and mediated effects (through self-care functions and self-control) on chronic self-destructiveness.
\end{abstract}

Keywords: chronic self-destructiveness, attachment, self-care function, self-control.

Słowa kluczowe: pośrednia autodestrukcyjność, przywiązanie, funkcje samoopiekuńcze, samokontrola.

\section{WPROWADZENIE}

Przedmiotem prezentowanego materiału jest próba empirycznej weryfikacji hipotezy o roli relacji przywiązania, a ściślej - lęku przed porzuceniem i unikania bliskości - oraz kompetencji samoopiekuńczych i zdolności do samoregulacji w wyjaśnianiu pośredniej autodestrukcyjności. Pojęcie autodestruktywności dotyczy szerokiego zakresu zjawisk o różnym obrazie klinicznym i przebiegu. Już wiele lat temu wśród licznych przejawów autodestrukcji została wyodrębniona 
jej mniej uchwytna i trudniej rozpoznawalna postać, szczególny rodzaj chronicznego ignorowania zagrożeń psychospołecznych i fizycznych, funkcjonujący pod nazwą ,,autodestrukcyjności pośredniej” lub „chronicznej” (Kelley i in., 1985; Suchańska, 1998). O jej specyfice decydują forma i cele zachowania oraz psychiczny dystans między działaniem i jego skutkiem. Cechuje się ona bowiem przewlekłością, transsytuacyjną powtarzalnością i pośredniością (tj. brakiem bezpośredniego ataku na siebie) oraz najczęściej jedynie potencjalnym lub odroczonym w czasie charakterem szkody, która stanowi raczej skutek uboczny niż cel zachowania (Suchańska, 1998). Z tego ostatniego względu mówi się o jej subintencjonalnym charakterze intencją człowieka nie jest bowiem atak na własne ciało czy życie, lecz spełnienie pragnienia mimo ewentualnych psychologicznych, społecznych czy fizycznych kosztów, częstokroć zresztą zaprzeczanych, racjonalizowanych lub minimalizowanych (Baumeister, Scher, 1988). Należy też mocno podkreślić, że nie chodzi tu o sporadyczne zaniedbania zdrowotne, osobiste i społeczne czy działania o potencjalnie negatywnych skutkach, co jest zjawiskiem powszechnym. To ich powtarzalność i różnorodność pozwala wnioskować o występowaniu uogólnionej tendencji autodestrukcyjnej. Sytuacyjnie uwarunkowane incydentalne zachowania potencjalnie szkodliwe, a także specyficzne klasy zachowań autodestrukcyjnych, jak uzależnienia czy ryzykanctwo, należy więc wyraźnie odróżnić od będącej przedmiotem tego opracowania osobowościowej tendencji (Suchańska, 2001). O autodestruktywnym charakterze opisanego sposobu funkcjonowania świadczy nie tylko sama jego forma, lecz także wykazane empirycznie długofalowe konsekwencje społeczne i zdrowotne (Suchańska, 1998).

Zdaniem Kathryn Kelley i współpracowników (1985) osoby funkcjonujące w opisany wyżej, pośrednio autodestrukcyjny sposób kierują się raczej czynnikami emocjonalnymi i doraźnymi korzyściami, aniżeli dalszymi konsekwencjami swojego zachowania. Podobnie wyjaśniają subintencjonalny charakter autodestrukcyjności Roy Baumeister i Steven Scher (1988), pisząc o przecenianiu doraźnych i niedocenianiu od- ległych następstw swoich działań, czyli o błędach bilansowania związanych z nimi kosztów i zysków. Autorzy zgodni są zatem co to tego, że kluczowym elementem intrapsychicznego mechanizmu zachowań autodestruktywnych jest niezdolność do podjęcia wysiłku niezbędnego do sprawowania samokontroli (Baumeister, 1997; Kelley i in., 1985; Suchańska, 2001). O ile jednak dla Kelley ochrona psychicznego i fizycznego zdrowia wydaje się bardziej społecznym (zewnętrznym) niż osobistym standardem, o tyle Baumeister w swoich nowszych pracach, omawiając zagadnienie samoregulacji (samokontroli ${ }^{1}$ ), wyraźnie akcentuje znaczenie osobistych standardów. Samokontrolę definiuje on bowiem jako zdolność do realizowania dalekich celów oraz takiego kierowania swoim zachowaniem, aby było ono zgodne z ideałami, wartościami, moralnością i oczekiwaniami społecznymi. Ta zdolność bazuje na dokonywaniu zamierzonych i dowolnych zmian swoich wewnętrznych reakcji (myśli, emocji, impulsów) oraz przerywaniu niepożądanych tendencji behawioralnych i powstrzymaniu się od działania na ich podstawie (Baumeister, Vohs, Tice, 2007). Tak pojmowana samokontrola, obejmująca realizację osobistych ideałów i wartości czy realizację dalekich celów, wydaje się zasobem dojrzałej osobowości i późniejszym osiągnięciem rozwojowym. U jego źródeł można wskazać naturalną zdolność do unikania zagrożeń fizycznych i psychicznych, wzmacnianą dzięki internalizacji reakcji i zachowań opiekuńczych matki. Chociaż próby wskazania na znaczenie tych wcześnie rozwijanych zasobów odpowiedzialnych za bezpieczne zachowanie się i samokontrolę nie są nowe, to brak w tym zakresie rozstrzygnięć empirycznych.

\section{Kompetencje samoopiekuńcze a pośrednia autodestruktywność}

Początkowo próby odpowiedzi na pytanie o osobowościowe uwarunkowania pośredniej autodestruktywności, utożsamianej wówczas z jej bezpośrednimi formami, skupiały się wokół klasycznych wyjaśnień psychoanalitycznych związanych z aktywnością popędów antylibidinalnych. Empirycznie wykazany brak istotnych związków pośredniej autodestruktywności z kierowaną prze- 
ciw sobie jawną i niejawną agresją stał się jednak inspiracją do poszukiwania innych źródeł tej formy szkodzenia sobie. Teorie psychologów ego (Hartmann, 1958; Hartmann, Loewenstein, 1962) oraz wstępnie zarysowany model uwarunkowań pośredniej autodestrukcyjności wskazywały na znaczenie wybranych funkcji ego związanych z internalizacją miłości i wczesnej opieki macierzyńskiej, funkcjonujących w literaturze przedmiotu pod nazwą ,funkcji samoopiekuńczych ego" (Khantzian, Mack, 1983). Na polskim gruncie konceptualizacja i próby operacjonalizacji konstruktu funkcji samoopiekuńczych mają już także pewną historię (Kozłowska, 2005; Sawicki, 2001; Suchańska, 1998, 2001). Definiowany jest on jako zdolność do dysponowania potencjałem funkcji i zachowań chroniących self, doświadczanego jako wartość i obiekt miłości.

Zgodnie z psychodynamicznym ujęciem rozwoju psychicznego podstawą kompetencji samoopiekuńczych człowieka jest internalizacja miłości matki, wraz z takimi aktami wczesnej opieki macierzyńskiej, jak kojenie (w tym kontenerowanie) emocji dziecka i zaspokajanie jego potrzeb, podtrzymywanie woli życia, rozpoznawanie i antycypacja zagrożeń (Khantzian, Mack 1983; Krystal, 1977). W dorosłym życiu prawidłowo ukształtowana zdolność do opiekowania się sobą powinna więc obejmować te zasoby w postaci poczucia własnej wartości, woli życia, zdolności samokojenia i samozaspokajania oraz kontroli impulsów.

$\mathrm{Z}$ teoretycznego punktu widzenia naturalnym kontekstem internalizacji macierzyńskiej miłości, troski i pełnionych przez matkę funkcji opiekuńczych powinna być bezpieczna relacja przywiązania (np. Bowlby, 1997/2007; Krystal, 1977). W późniejszych okresach życia bezpieczne przywiązanie wyraża się jako zdolność do budowania bliskich relacji z innymi ludźmi, wolnych od lęku przed odrzuceniem i unikania bliskości (Hazan, Shaver, 1987).

\section{Przywiązanie i jego rola w rozwoju funkcji samoopiekuńczych i samoregulacji}

Jednym z głównych założeń teorii przywiązania jest fakt, że w relacji przywiązania system behawioralno-poznawczo-afektywny two- rzy reprezentacje relacji dziecka z opiekunem (tzw. wewnętrzne modele operacyjne; Bowlby, 1997/2007). Proces ten wraz z rozwojem mowy ulega przekształceniu z sensomotorycznego w symboliczny (Oatley, Jenkins, 2003). Uformowane na bazie wczesnodziecięcych doświadczeń reprezentacje self, figury przywiązania i relacji między nimi stają się w przyszłości podstawą spostrzegania siebie i innych oraz wyznaczają sposób myślenia, odczuwania i zachowywania się $\mathrm{w}$ relacjach $\mathrm{z}$ bliskimi osobami (Collins, Guichard, Ford, Feeney, 2004). Jeśli są one obarczone lękiem przed porzuceniem, mogą blokować lub znacznie utrudniać rozwój ufności, siły i kontroli. Z kolei reprezentacje prowadzące do unikania bliskości mogą rodzić poczucie osamotnienia, utrudniać dostęp do pozytywnych doświadczeń interpersonalnych i okazać się przeszkodą w sięganiu po pomoc i wsparcie w sytuacjach emocjonalnie trudnych. Obecność i osiągalność opiekuna, niezbędna dla regulacji własnych stanów i reakcji dziecka (Stawicka, 2008), dzięki internalizacji tego doświadczenia staje się w dorosłości własnym zasobem osoby $\mathrm{w}$ radzeniu sobie $\mathrm{z}$ emocjami i stresem. Zasadne jest zatem oczekiwanie, że lęk i unikanie bliskości, blokując podstawowe komponenty kompetencji samoopiekuńczych i gotowości do samokontroli, zwiększają prawdopodobieństwo rozwoju tendencji autodestrukcyjnych.

Przedstawiony tok rozumowania prowadzi do próby zaproponowania modelu uwarunkowań pośredniej autodestrukcyjności. Uwzględnia on powiązane wzajemnie, główne komponenty stylu przywiązania, na które składają się poziom lęku przed odrzuceniem i unikania bliskości w relacjach przywiązaniowych, złożone kompetencje samoopiekuńcze oraz zdolność do samokontroli. Opierając się na przedstawionych wyżej przesłankach teoretycznych, hipotetycznie przyjęto, że przywiązanie bezpieczne (z niskim poziomem lęku i unikania) będzie wspomagać kompetencje samoopiekuńcze, które z kolei sprzyjać będą zdolności do samokontroli i bezpiecznego (niedestrukcyjnego) funkcjonowania. Przywiązaniowy lęk lub unikanie (ze względu na różnie wartościowane reprezentacje self i figury przywiązania) osłabiać będą natomiast motywację do samoopieki i samoochrony czy 
do sięgania po wsparcie ze strony innych. Empiryczna weryfikacja tego modelu jest celem prezentowanego $\mathrm{w}$ artykule badania.

\section{METODA}

\section{Osoby badane}

W badaniu wzięło udział 137 osób, wśród których 54\% stanowiły kobiety. Wiek osób badanych zawierał się w przedziale od 18 do 31 lat $(M=23.85, S D=2.47)$. Większość $\mathrm{z}$ nich deklarowała wykształcenie wyższe $(60 \%)$ lub średnie (39\%). Badanie zrealizowano w trybie indywidualnym, za pośrednictwem ankiety internetowej. Udział w badaniu wszystkich osób był anonimowy i dobrowolny.

Wybór młodych dorosłych jako grupy badanej podyktowany był doniesieniami z innych badań wskazującymi, że wśród osób o najwyższym nasileniu pośredniej autodestruktywności przeważają te w okresie wczesnej dorosłości (Boudewyn, Liem, 1995; Kelley i in., 1985).

\section{Narzędzia badawcze}

Do pomiaru przywiązania w dorosłości wykorzystano Kwestionariusz Doświadczeń w Bliskich Związkach (Experiences in Close Relationship Scale; Brennan, Clark, Shaver, 1998) w polskiej adaptacji Karoliny Rajewskiej-Rynkowskiej (2007). Kwestionariusz obejmuje 36 pozycji ocenianych na 7-stopniowej skali (od „Całkowicie się nie zgadzam” do „Całkowicie się zgadzam"), które dzielą się na dwie podskale odpowiadające przywiązaniowym dymensjom lęku i unikania. Pozycje podskali lęku dotyczą obaw związanych z odrzuceniem, brakiem dostępności i uważności bliskiej osoby (np. „Bardzo się boję, że stracę tę osobę”), pozycje podskali unikania zaś odnoszą się do obaw związanych z zależnością, intymnością i odsłanianiem się (np. ,Wolę nie okazywać tej osobie, co tak naprawdę czuję"). Parametry psychometryczne kwestionariusza w polskim przekładzie są zadowalające i zbliżone do wersji oryginalnej (Karbowa-Płowens, 2017; Rajewska-Rynkowska, 2007). W prezentowanym badaniu współczynniki rzetelności alfa Cronbacha wyniosły $\alpha=.92$ i $\alpha=.95$, odpowiednio dla podskali lęku i unikania.

Zdolność do samoopieki badano za pomocą Kwestionariusza Kompetencji Samoopiekuńczych w jego najnowszej wersji (Brzeg, Suchańska, 2017). Kwestionariusz liczy 24 pozycje oceniane na 5-stopniowej skali - od „Zdecydowanie się nie zgadzam” do „Całkowicie się zgadzam". Pozycje te odnoszą się do takich przejawów funkcji samoopiekuńczych, jak: poczucie własnej wartości i wartości własnego życia, umiejętność samokojenia i samozaspokajania, rozpoznawanie i różnicowanie stanów afektywnych i kontrola emocjonalna oraz poznawcza regulacja zachowania i symbolizacja norm (np. „Potrafię znaleźć w sobie oparcie, gdy sytuacja tego wymaga”, „Wiem, kiedy strach komunikuje realne zagrożenie"). Rzetelność kwestionariusza, oszacowana za pomocą współczynnika alfa Cronbacha, wyniosła $\alpha=.90$.

W pomiarze zdolności do samokontroli użyta została Skala Samokontroli (Self-Control Scale; Tangney, Baumeister, Boone, 2004) w polskiej adaptacji Aleksandry Pilarskiej (2016; Pilarska, Baumeister, 2018). Skala obejmuje 36 pozycji, które umożliwiają pomiar takich przejawów samokontroli, jak: kontrola myśli, kontrola emocji, kontrola impulsów, optymalizacja poziomu wykonania, przełamywanie nawyku (np. „Często działam pod wpływem chwili”, „Trudno jest mi pozbyć się złych nawyków”). Podążając za sugestią Jonathana Hasforda i Kelly Bradley (2011), zastosowano 7-stopniową skalę odpowiedzi: od "Wcale mnie nie opisuje" do „Bardzo dobrze mnie opisuje”. Polska wersja skali cechuje się satysfakcjonującą trafnością i rzetelnością (Pilarska, Baumeister, 2018). Obliczony w badaniu własnym współczynnik rzetelności alfa Cronbacha wyniósł $\alpha=.89$.

Skala Pośredniej Autodestruktywności (Chronic Self-Destructiveness Scale; Kelley $\mathrm{i}$ in., 1985), zaadaptowana do warunków polskich przez Annę Suchańską (1998), posłużyła do pomiaru tendencji autodestruktywnej. Na skalę składają się 52 twierdzenia, odmienne dla kobiet i mężczyzn (np. „Staram się raczej podróżować bezpiecznie aniżeli szybko”, „Często używam lekarstw nieprzepisanych przez lekarza"). Od- 
powiedzi udziela się na 5-stopniowej skali - od „Zdecydowanie się nie zgadzam” do „Całkowicie się zgadzam”. Skala posiada zadowalające właściwości psychometryczne (Suchańska, 1998). W prezentowanym badaniu współczynnik rzetelności alfa Cronbacha wyniósł $\alpha=.88 \mathrm{dla}$ kobiet oraz $\alpha=.84$ dla mężczyzn.

\section{WYNIKI}

Do celów analizy opisowej obliczono średnie i odchylenia standardowe dla wszystkich zmiennych w całej badanej grupie, jak również oddzielnie dla kobiet i mężczyzn. Zostały one przedstawione w tabeli 1. Porównania średnich wyników wśród kobiet i mężczyzn, przeprowadzone z wykorzystaniem testu $t$-Studenta lub jego nieparametrycznego odpowiednika - testu $U$ Manna-Whitneya, wykazały istotne różnice między grupami w odniesieniu do unikania $(Z=$ $-3.12, p<.01)$ oraz pośredniej autodestruktywności $(Z=-2.25, p<.05)$. Mężczyzn cechowało wyższe nasilenie unikania oraz pośredniej autodestruktywności w porównaniu z kobietami.

Zebrane dane były analizowane dalej w dwóch etapach. W pierwszym zastosowano analizę korelacji $r$ Pearsona dla określenia wzajemnych powiązań między mierzonymi zmiennymi. W drugim etapie wykorzystano analizę ścieżek do oceny bezpośrednich i pośrednich efektów przywiązania na pośrednią autodestrukcyjność. Ponieważ dane nie spełniały założenia o wielowymiarowej normalności rozkładu, w analizie wykorzystano estymator największej wiarygodności z korektą zaproponowaną przez Alberta Satorrę i Petera Bentlera (1994).

Wyniki pierwszego etapu analiz prezentuje tabela 1. Jak wynika z przedstawionych w niej danych, doświadczanie lęku i unikania związanego z przywiązaniem współwystępowało $\mathrm{z}$ deficytami w zakresie zdolności samoopieki $(r=-.37 \mathrm{i} r=-.39, p<.001$ odpowiednio dla lęku i unikania) i samokontroli $(r=-.50$ i $r=$ $-.17, p<.05$ odpowiednio dla lęku i unikania) oraz z wyższym natężeniem pośredniej autodestruktywności $(r=.45$ i $r=.30, p<.001$ odpowiednio dla lęku i unikania). Z kolei zdolności samoopieki i samokontroli łączyły się z pośrednią autodestruktywnością ujemnie $(r=-.45$ i $r=-.72, p<.001$ odpowiednio dla samoopieki i samokontroli), przy czym szczególnie wyraźna była ujemna korelacja pośredniej autodestruktywności z samokontrolą.

Tabela 1. Statystyki opisowe oraz współczynniki korelacji między dymensjami przywiązania, zdolnościami do samoopieki i samokontroli oraz pośrednią autodestruktywnością

\begin{tabular}{|l|c|c|c|c|c|c|c|}
\hline \multirow{2}{*}{ Zmienna } & $\mathbf{2}$ & $\mathbf{3}$ & $\mathbf{4}$ & $\mathbf{5}$ & Ogólem & Kobiety & $\begin{array}{c}\text { Męż- } \\
\text { czyźni }\end{array}$ \\
\cline { 5 - 8 } & & & & & $\boldsymbol{M}$ (SD) & $\boldsymbol{M}$ (SD) & $\boldsymbol{M}$ (SD) \\
\hline 1. Lęk & $.23^{* *}$ & $-.37^{* * *}$ & $-.50^{* * *}$ & $.45^{* * *}$ & $3.87(1.28)$ & $3.94(1.25)$ & $3.79(1.32)$ \\
\hline 2. Unikanie & - & $-.39^{* * *}$ & $-.17^{*}$ & $.30^{* * *}$ & $2.43(1.22)$ & $2.18(1.22)$ & $2.72(1.16)$ \\
\hline 3. Samoopieka & & - & $.48^{* * *}$ & $-.45^{* * *}$ & $3.83(0.56)$ & $3.85(0.53)$ & $3.81(0.59)$ \\
\hline 4. Samokontrola & & & - & $-.72^{* * *}$ & $4.14(0.77)$ & $4.12(0.82)$ & $4.18(0.71)$ \\
\hline $\begin{array}{l}\text { 5. Pośrednia auto- } \\
\text { destruktywność }\end{array}$ & & & & - & $2.45(0.43)$ & $2.37(0.44)$ & $2.53(0.40)$ \\
\hline
\end{tabular}

$* * * p \leq .001, * * p \leq .01, * p<.05$

Zasadniczą część analiz przeprowadzono $\mathrm{w}$ modelu ścieżek. Weryfikowano model z mediacją dwukrokową, w którym związek dymensji przywiązania (tj. lęku przed odrzuceniem i unikania intymności) z pośrednią autodestruktywnością wyjaśniały dwa, następujące po sobie, mediatory - zdolności samoopieki i samokontroli. Z uwagi na różnice badanych zmiennych wśród kobiet i mężczyzn w modelu uwzględniono oddziaływanie czynnika płci. Wychodząc od modelu wyjściowego, testowano kolejne modele zagnieżdżone, które powstały przez usuwanie ścieżek, tak aby otrzymać model uproszczony, w którym wszystkie ścieżki 
byłyby istotne na poziomie co najmniej $p<.05$. Ostateczny model uproszczony był dobrze dopasowany do danych $w$ świetle miar dopasowania $\left(\chi^{2}=5.10, d f=6, p>.05, \mathrm{CFI}=1.00, \mathrm{RMSEA}=\right.$ .00$, SRMR $=.03)$. Model ten przedstawiono na rysunku 1.

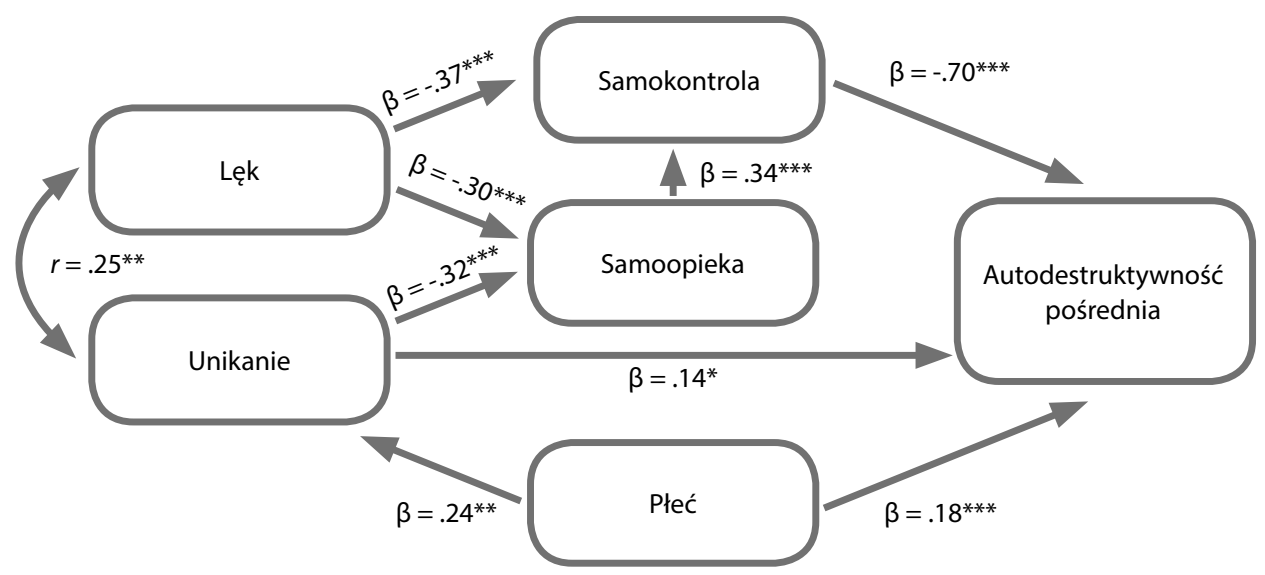

$* p<.05, * * p<.01, * * * p<.001$

Rysunek 1. Bezpośrednie i pośrednie związki dymensji przywiązania z pośrednią autodestruktywnością (współczynniki standaryzowane)

Obie dymensje przywiązania w sposób znaczący i ujemny wiązały się ze zdolnościami $\mathrm{w}$ zakresie samoopieki $(\beta=-.30$ i $\beta=-.32$, $p \leq .001$ odpowiednio dla lęku i unikania) i wyjaśniały ich zmienność w $24 \%$. W przypadku samokontroli ujawnił się bezpośredni negatywny wpływ lęku $(\beta=-.37, p<.001)$. Ponadto obie przywiązaniowe dymensje ujemnie oddziaływały na możliwości samokontroli w sposób pośredni, to jest poprzez deficyty w zakresie zdolności samoopieki (efekty pośrednie $=-.10$ oraz -.11, $p<.05$ odpowiednio dla lęku i unikania). Te ostatnie, jak można było oczekiwać, były ważnym, dodatnim predyktorem siły samokontroli $(\beta=.34, p<.001)$. Dymensje przywiązania i funkcja samoopiekuńcza łącznie wyjaśniały $35 \%$ wariancji samokontroli.

Rezultaty testowań bezpośrednich i pośrednich wpływów przywiązania na pośrednią autodestruktywność pokazały, że związek lęku przed odrzuceniem $\mathrm{z}$ pośrednią autodestruktywnością miał charakter jedynie pośredni jego wpływy zachodziły w pierwszej kolejności poprzez samokontrolę (efekt pośredni $=.26$, $p<.001$ ), a częściowo także dłuższą ścieżką poprzez funkcję samoopiekuńczą i samokon- trolę (efekt pośredni $=.07, p<.05)$. Oba efekty lęku dla pośredniej autodestruktywności były dodatnie, a zatem obecność przywiązaniowego lęku znajdowała wyraz w deficytach funkcji samoopiekuńczej oraz zdolności samokontroli, a w rezultacie sprzyjała podejmowaniu zachowań samoniszczących.

W odniesieniu do unikania intymności analiza ujawniła zarówno efekt bezpośredni ( $\beta=$ $.14, p<.05)$, jak i - nieco słabszy - dwukrokowy efekt pośredni prowadzący przez funkcję samoopiekuńczą i samokontrolę (efekt pośredni $=.08, p<.01)$. Zarówno bezpośredni, jak i pośredni wpływ unikania na autodestruktywność był dodatni - obecność unikania pozwalała przewidywać częstsze podejmowanie zachowań samoniszczących.

W sumie model wyjaśniał $60 \%$ wariancji pośredniej autodestruktywności. W analizie porównawczej najsilniejszymi predyktorami tendencji autodestruktywnej były zdolności w zakresie samokontroli (efekt całkowity = -.70) oraz lęk przed odrzuceniem (efekt całkowity $=.33)$, nieco słabszymi zaś zdolności w zakresie samoopieki (efekt całkowity $=-.24$ ) oraz unikanie bliskości (efekt całkowity=.22). 


\section{DYSKUSJA I WNIOSKI}

Otrzymane rezultaty wskazują na dobre dopasowanie zaproponowanego teoretycznego modelu do danych empirycznych. Tym samym wspierają hipotezę, zgodnie z którą pozabezpieczne przywiązanie stanowi istotny czynnik ryzyka deficytów w obszarze zdolności do samoopieki i samokontroli, a w konsekwencji - chronicznych samoniszczących tendencji osobowościowych. Wskazują przy tym na użyteczność uwzględniania kompetencji samoopiekuńczych i samokontroli dla zrozumienia psychologicznych uwarunkowań pośredniej autodestruktywności, profilaktyki i interwencji w tym obszarze.

Obraz szczegółowych powiązań między poszczególnymi elementami modelu po części stanowi potwierdzenie wyników dotychczasowych badań lub analiz teoretycznych, po części zaś wnosi nowe dane do posiadanej wiedzy. $\mathrm{Na}$ przykład obserwacja dotycząca roli lęku przed porzuceniem i unikania bliskości dla nasilenia pośredniej autodestruktywności jest zbieżna z wynikami wcześniejszych badań nad znaczeniem wzorca przywiązania dla podejmowania zachowań samoniszczących (Bartnik-Matyska, 2002; Schwark, Cierpiałkowska, 2016). Rezultaty niniejszego badania stanowią także empiryczne poparcie kierunku myślenia zaprezentowanego w tych teoretycznych opracowaniach uwarunkowań zjawiska pośredniej autodestrukcyjności, w których wskazywano na znaczenie funkcji samoopiekuńczej, rozumianej jako efekt internalizacji macierzyńskiej miłości i opieki, dla troski o własne zdrowie i życie (Krystal,1977; Orbach, 1996; Suchańska, 1998).

Hipotetycznie zakładana w zaproponowanym modelu, a potwierdzona w drodze analizy mediacji, relacja między lękowym przywiązaniem a pośrednią autodestrukcyjnością zapośredniczona jest przez kompetencje samoopiekuńcze i samokontrolę. Lęk relacyjny sprzyja zatem wykształceniu się tendencji pośrednio autodestruktywnej, ponieważ osłabia zdolności do samoopieki i samokontroli. Zaprezentowany model i wnioski z przeprowadzonych analiz dotyczą osób dorosłych i samoopisu ich obecnych doświadczeń. Biorąc jednak pod uwagę, zakładaną przez teoretyków i badaczy przywią- zania, pewną ciągłość wzorca przywiązania na przestrzeni życia, ujawniony w modelu bezpośredni wpływ lęku na zdolności do opiekowania się i kontroli siebie empirycznie ilustrowałby również tezę o istotnym znaczeniu obecności i osiągalności opiekuna dla regulacji własnych stanów i reakcji (Stawicka, 2008).

O ile w przypadku lęku przed porzuceniem mediacja miała charakter całkowity (innymi słowy, lęk przed porzuceniem warunkował tendencje pośrednio autodestruktywne jednie $\mathrm{w}$ takim stopniu, w jakim skutkował zakłóceniem w obrębie zdolności samoopieki i samokontroli), o tyle w odniesieniu do unikania intymności mediacja miała charakter jedynie częściowy. Odrzucanie emocjonalnej bliskości z innymi pozwalało przewidywać nasilone tendencje pośrednio autodestruktywne zarówno w sposób pośredni, jak i bezpośredni. Choć w modelu związek bezpośredni jest dość słaby, oznacza on, że strategia unikania bliskości w relacji może stanowić czynnik ryzyka autodestrukcyjności nie tylko z powodu deficytu kontroli i niezdolności do samoopieki, ale również $\mathrm{z}$ uwagi na inne czynniki, być może stanowiące pochodnecharakterystycznego dla unikającego typu przywiązania - negatywnego stosunku do figury przywiązania.

W świetle weryfikowanego modelu pośrednia autodestruktywność wydaje się najsilniej powiązana $\mathrm{z}$ niepowodzeniami w samokontroli. Wynik ten stanowi poparcie dla proponowanej zarówno przez Kelley, jak i przez Baumeistera tezy o kluczowej roli tego zasobu w wyjaśnianiu pośredniej autodestrukcyjności. Warto jednak pamiętać, że chociaż teoretycznie są to różne konstrukty, to ich operacjonalizacja (pozycje testowe) zawiera pewien obszar wspólny, co może być czynnikiem częściowo odpowiedzialnym za ich obserwowaną współzależność.

Podsumowując, otrzymane rezultaty umacniają tezę, zgodnie $\mathrm{z}$ którą $\mathrm{w}$ genezie chronicznych tendencji pośrednio autodestrukcyjnych pozabezpieczne przywiązanie stanowi ważny czynnik ryzyka. Wskazują jednocześnie na użyteczność uwzględniania zdolności samoopieki i samokontroli dla zrozumienia, z jednej strony, sposobów oddziaływania zaburzeń więzi, a z drugiej - psychologicznych mechanizmów pośredniej auto- 
destruktywności. Badanie i wyprowadzone na jego podstawie wnioski mają jednak pewne ograniczenia. Dotyczą przede wszystkim internetowego sposobu zbierania danych, który uniemożliwia pełną kontrolę procedury oraz wykorzystania samoopisowych metod pomiaru, podatnych na zniekształcenia wynikające, dla przykładu, z aktywizacji potrzeby aprobaty społecznej.

\title{
PRZYPIS
}

\begin{abstract}
$1 \quad$ Niektórzy autorzy stosują tu subtelne rozróżnienie, wskazując, że samokontrola odnosi się do świadomego i celowego panowania nad własnymi reakcjami, podczas gdy samoregulacja obejmuje także inne, nieświadome (np. fizjologiczne) procesy regulacji (Baumeister, Vohs, Tice, 2007). W ramach koncepcji R. Baumeistera oba pojęcia używane są zamiennie.
\end{abstract}

\section{BIBLIOGRAFIA}

Bartnik-Matyska B. (2002), Styl przywiazania i jego zwiazek z autodestruktywnościa pośrednią. Niepublikowana praca magisterska. Poznań: Instytut Psychologii UAM.

Baumeister R.F. (1997), Esteem threat, self-regulatory breakdown, and emotional distress as factors in selfdefeating behavior. Review of General Psychology, 1(2), 145-174.

Baumeister R.F., Scher S.J. (1988), Self-defeating behavior patterns among normal individuals: Review and analysis of common self-destructive tendencies. Psychological Bulletin, 104(1), 3-22.

Baumeister R.F., Vohs K.D., Tice D.M. (2007), The strength model of self-control. Current Directions in Psychological Science, 16(6), 351-355.

Bowlby J. (1997/2007), Przywiazanie. Warszawa: Wydawnictwo Naukowe PWN.

Boudewyn A.C., Liem J.H. (1995), Psychological, interpersonal, and behavioral correlates of chronic selfdestructiveness: An exploratory study. Psychological Reports, 77(3), 1283-1297.

Brennan K.A., Clark C.L., Shaver P.R. (1998), Self-report measurement of adult attachment: An integrative overview. W: J.A. Simpson, W.S. Rholes (eds.), Attachment Theory and Close Relationships, 46-76. New York: Guilford.

Brzeg J., Suchańska A. (2017), Kwestionariusz kompetencji samoopiekuńczych. Materiały niepublikowane. Poznań: Instytut Psychologii UAM.

Collins N.L., Guichard A.C., Ford M.B., Feeney B.C. (2004), Working models of attachment. New developments and emerging themes. W: W.S. Rholes, J.A. Simpson (eds.), Adult Attachment. Theory, Research, and Clinical Applications, 196-236. New York: Guilford Publications.

Hartmann H. (1958), Ego Psychology and the Problem of Adaptation. New York: International Universities Press. Hartmann H., Loewenstein R.M. (1962), Notes on the superego. The Psychoanalytic Study of the Child, 17, 42-81. Hasford J., Bradley K.D. (2011), Validating measures of self-control via Rasch measurement. Journal of Applied Business Research, 27(6), 45-56.

Hazan C., Shaver P. (1987), Romantic love conceptualized as an attachment process. Journal of Personality and Social Psychology, 52(3), 511-524.

Karbowa-Płowens M. (2017), Diagnoza stylów przywiązania za pomocą kwestionariusza ECR. W: W.J. Paluchowski (red.), Diagnozowanie. Wyzwania i konteksty, 203-222. Poznań: Wydawnictwo Naukowe WNS UAM.

Kelley K., Byrne D., Przybyla D.P.J., Eberly C., Eberly B., Greendlinger V., Gorsky J. (1985), Chronic selfdestructiveness: Conceptualization, measurement, and initial validation of the construct. Motivation and Emotion, 9(2), 135-151.

Khantzian E.J., Mack I.E. (1983), Self-preservation and the care of the self. Ego instincts reconsidered. The Psychoanalytic Study of the Child, 38, 209-232.

Kozłowska J. (2005), Style przywiazania a funkcje samoopiekuńcze. Niepublikowana praca magisterska. Poznań: Instytut Psychologii UAM. 
Krystal H. (1977), Self-representation and the capacity for self care. Annual of Psychoanalysis, 6, 209-246.

Oatley K., Jenkins J. (2003), Zrozumieć emocje. Warszawa: Wydawnictwo Naukowe PWN.

Orbach I. (1996), The role of the body experience in self-destruction. Clinical Child Psychology and Psychiatry, 1(4), 607-619.

Pilarska A. (2016, lipiec), Polish translation and cross-language validation of the Self-Control Scale. Poster na konferencji Motivation and Social Perception. Gdańsk.

Pilarska A., Baumeister R.F. (2018). Psychometric properties and correlates of the Polish version of the Self-Control Scale (SCS). Polish Psychological Bulletin, 49(1), 95-106.

Rajewska-Rynkowska K. (2007), Schematy przywiazania do obiektu religijnego w kontekście aktywacji myśli o śmierci. Niepublikowana rozprawa doktorska. Poznań: Instytut Psychologii UAM.

Satorra A., Bentler P.M. (1994), Corrections to test statistics and standard errors in covariance structure analysis. W: A. von Eye, C.C. Clogg (eds.), Latent Variables Analysis: Applications for Developmental Research, 399-419. Thousand Oaks, CA: Sage Publications.

Sawicki I. (2001), Funkcje samoopiekuńcze a autodestruktywność pośrednia. Niepublikowana praca magisterska. Poznań: Instytut Psychologii UAM.

Schwark A., Cierpiałkowska L. (2016), Autodestruktywność pośrednia a styl przywiązania. Czasopismo Psychologiczne, 22(1), 73-80.

Stawicka M. (2008), Autodestruktywność dziecięca w świetle teorii przywiązania. Poznań: Wydawnictwo Naukowe UAM.

Suchańska A. (1998), Przejawy i uwarunkowania psychologiczne pośredniej autodestruktywności. Poznań: Wydawnictwo Naukowe UAM.

Suchańska A. (2001), W poszukiwaniu wyjaśnień samoniszczenia. Samoniszczenie a kompetencje samoopiekuńcze. Forum Oświatowe, 2(25), 61-73.

Tangney J.P., Baumeister R.F., Boone A.L. (2004), High self-control predicts good adjustment, less pathology, better grades, and interpersonal success. Journal of Personality, 72(2), 271-324. 